\title{
Relation Between Prakriti and Stress Handling Capacity: An Observational Study
}

\section{IJCRR}

Section: Healthcare Sci. Journal Impact Factor: 6.1 (2018) ICV: 90.90 (2018)

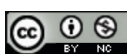

Copyright@IJCRR

\section{Deepali Giri ${ }^{1}$, Sonali Wairagade ${ }^{2}$, Priti Desai ${ }^{3}$, Abhilasha Agrawal ${ }^{4}$, Roshan Kumar Jha ${ }^{5}$}

\begin{abstract}
'Professor, Department of Rachana Sharir, Datta Meghe Ayurvedic Medical College Hospital \& Research Center, Wanadongri, Nagpur, India; 'Associate Professor, Department of Kayachikitsa, Datta Meghe Ayurvedic Medical College, Wanadongri, Nagpur, India; ${ }^{3}$ Professor, Department of Rachana Sharir, Mahatma Gandhi Ayurvedic College \& Hospital, Salod, Wardha, India; ${ }^{4}$ Associate Professor, Department of Kriya Sharir, R. D. Memorial PG Ayurved College and Hospital, Bhopal, India; ${ }^{5}$ Tutor Department of Biochemistry Jawaharlal Nehru Medical College, Datta Meghe Institute of Medical Sciences, Wardha, India.
\end{abstract}

\section{ABSTRACT}

Introduction: Stress is the major cause of many diseases. The list of diseases ranges from hypertension, diabetes to alcoholism. Ayurveda divides the population according to the Prakriti of an individual. There are seven types of Prakriti. Each Prakriti has a typical psychosomatic constitution. Prakriti of an individual can be assessed with the help of the characteristics that are described in ancient Ayurveda texts. Assessment of Prakriti can be helpful in determining the stress handling capacity of a person and ultimately helping him to keep stress-induced diseases away.

Material and method: Online survey forms of Prakriti and stress handling capacity were distributed to 200 students. Out of 200 students 138 responses were received. Prakriti and stress handling capacity was assessed from the responses received. The data was compared to look for the relationship in them, if any.

Conclusion: Kapha and Pitta found to be the most important factors in the psychosomatic composition of a person. People with the dominance of Vata are more prone to stress induced diseases. The occurrence of stress induced diseasescan be reduced with proper stress management.

Key Words: Prakriti, Stress, Stress handling, Psychosomatic constitution, Stress-induced diseases

\section{INTRODUCTION}

Ayurveda, the system of Indian medicine, uses the assessment tool for individual examination of a person. This tool is known as Prakriti. ${ }^{1}$ According to Ayurveda, the definition of perfect health is as follows; when all the Dosha -vital elements including hormones and biochemical secretions in the human body, Dhatu - all the tissues in the human body, Agni ${ }^{2}$ -capacity of a person to make the ingested food available for all the tissues and mala - waste products in the human body in a person are in equilibrium along with a cheerful soul and mind, he is said to be in the condition of perfect health. ${ }^{3}$ Cheerful mind is equally important for a healthy state of a person. ${ }^{4}$ Mind, soul and body are the three pillars of a person. Tridosha and Triguna are the basic concepts of Ayurveda. Vata, Pitta, and Kapha are the Doshas and they are the physical factors responsible for the healthy status of a person whereas Triguna i.e. Sattva, Raja and Tama are responsible for mental health. ${ }^{5}$
Tridosha is also responsible for the physical constitution of a person. Seven types of constitutions are formed with different combinations of Doshas. These combinations are known as Prakriti. These constitutions are further classified into seven types according to the dominance of the Doshas namely Vataja, Pittaja, Kaphaja, Kaphavataja, Kaphapittaja, Vatapittaja and Sama Prakriti. ${ }^{6}$ Vataja, Pittaja, Kaphaja Prakriti, and Sama Prakriti occur in less population whereas Kaphavataja, Kaphapittaja, and Vatapittaja are more common.

Physical and mental characters of each Prakriti are described in Ayurveda. Characteristic features of physical Prakriti include physical qualities as well as psychological qualities. ${ }^{7}$

The capacity to manage stress is different in each individual. Stress handling capacity (SHC) can vary along with the types of Prakriti. This study is initiated to verify if there is any relation in Prakriti and SHC of a person.

\section{Corresponding Author:}

Dr. Deepali Giri, Professor, Department of Rachana Sharir, Datta Meghe Ayurvedic Medical College Hospital \& Research Center, Wanadongri, Nagpur, India.

ISSN: 2231-2196 (Print)

Received: 15.05 .2020
ISSN: $0975-5241$ (Online)

Revised: 05.07 .2020
Accepted: 15.07.2020 


\section{Objectives of the Study}

Stress is the main etiological factor for many diseases. If we could be able to guess the SHC of a person, we would be able to prevent stress-induced diseases. The objectives of the study are to assess the Prakriti of the volunteers and to assess their SHC.

\section{MATERIALS AND METHODS}

\section{Population}

For the present study (Ethical no-DMIMS (DU)/ IEC/2020/8852) the students of either gender aged between 18-25 years and registered during the years 2018 and 2019 under the Bachelor of Ayurveda Medicine and Surgery (BAMS) were considered.

\section{Assessment of Prakriti}

We have used the "Self-assessment questionnaire" originally prepared by Kishor Patwardhan and Rashmi Sharma, modified by Piyush Kumar Tripathi, Kishor Patwardhan, and Girish Singh, Institute of Medical Sciences, Banaras Hindu University, Varanasi. ${ }^{8}$ The questionnaire has been already validated by the authors so it was used as it was available.

The questionnaire for SHC was prepared and used for the study. SHC was graded as excellent, good, average, and poor according to the scores. The questionnaire was administered online for self-assessment. It was sent to a total of 200 volunteers. Out of them, 138 responses were received. Prakriti and SHC were assessed using the received data. Seven types of Prakriti were sorted and separated. SHC of each individual was compared with their Prakriti.

\section{STATISTICAL ANALYSIS}

Data were collected in an excel sheet and analysed by using SPSS software (23.0 Version)

\section{Observations:}

Total of 138 responses were received out of which the number of female volunteers was 97 and the number of male volunteers was 41. The number of Vata Prakriti and Pitta Prakritivolunteers was 5 each whereas 6 volunteers had $\mathrm{Ka}$ pha Prakiti. Volunteers with dual Prakriti were 108. 31 had Kaphapitta, 43 had Kaphavata, and 34 had Vatapitta Prakriti. 14 volunteers had Sama Prakriti.

\section{Table 1: Type of Prakriti and Number of volunteers}

$\begin{array}{llc}\text { Sr. no. } & \text { Prakriti } & \text { No. of volunteers } \\ \text { 1. } & \text { Vata } & 5 \\ \text { 2. } & \text { Pitta } & 5 \\ \text { 3. } & \text { Kapha } & 6\end{array}$

\section{Table 1: (Continued)}

\begin{tabular}{llc} 
Sr. no. & Prakriti & No. of volunteers \\
\hline 4. & Kaphapitta & 31 \\
5. & Kaphavata & 43 \\
6. & Vatapitta & 34 \\
7. & Sama & 14 \\
8. & Total & 138 \\
\hline
\end{tabular}

Total 138 volunteers participated in the study. Numbers of Vata, Pitta and Kapha Prakriti people were 5, 5, and 6, respectively. Duel Prakriti people i.e. Kaphapitta Prakriti, Kaphavata Prakriti, Vatapitta Prakritiwere 31, 43, and 34. People with some Prakriti were 14.

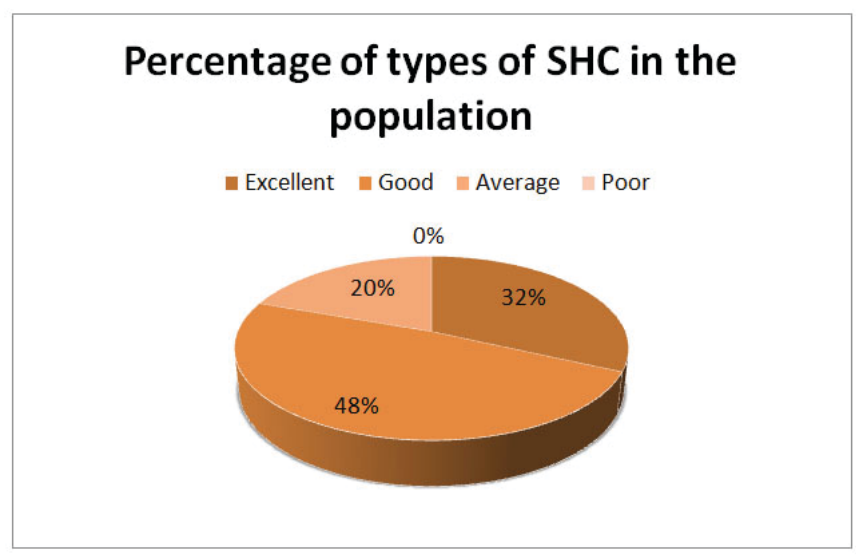

Figure 1: Percentage of types of SHC in the population.

$44(31.88 \%)$ volunteers had excellent stress handling capacity (SHC), 67 (48.55\%) volunteers had good SHC, and 27 (19.57\%) volunteers had average SHC. No volunteer had poor SHC.

Table 2: Prakriti Wise Distribution of Volunteers with Excellent SHC

$\begin{array}{lcc}\text { Prakriti } & \begin{array}{c}\text { Total number of } \\ \text { volunteers with } \\ \text { excellent SHC }\end{array} & \begin{array}{c}\text { Percentage of volun- } \\ \text { teers with excellent } \\ \text { SHC (within the group) }\end{array} \\ \text { Vata } & 0 & 0 \\ \text { Kapha } & 1 & 2.27 \\ \text { Pitta } & 1 & 2.27 \\ \text { Kaphapitta } & 16 & 36.36 \\ \text { Kaphavata } & 11 & 25.00 \\ \text { Vatapitta } & 10 & 22.73 \\ \text { Sama } & 5 & 11.36 \\ \text { Total } & 44 & 100\end{array}$


The above table no 2 shows the Prakriti Wise Distribution of Volunteers with Excellent SHC

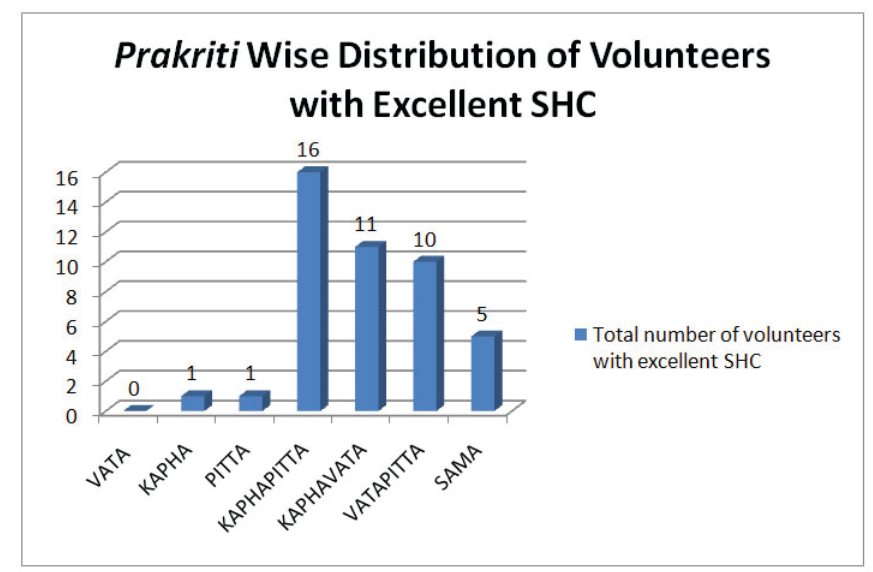

Figure 2A: Prakriti Wise Distribution of Volunteers with Excellent SHC.

In table no 2 and fig. no 1 showed Out of 138 participants, 44 participants had excellent SHC. Only one participant each with Kapha and Pitta Prakriti had excellent SHC. No person with Vata Prakriti had excellent SHC. The highest number of participants with excellent SHC was from the group of Kaphapitta Prakriti. The number of Kaphavata and Vatapitta prakriti with excellent SHC was 11 and 10, respectively. 5 participants with Sama Prakriti had excellent SHC.

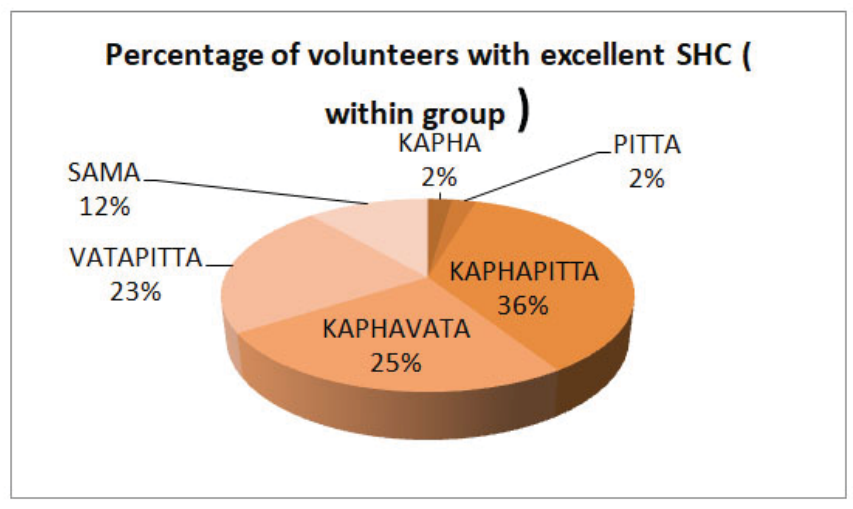

Figure 2B: Percentage of volunteers with excellent SHC (within the group).

Diag. no 2 showed Duel Prakriti comprise $84 \%$ of the population of the group. Kaphapitta Prakriti people are $36.36 \%$ of the group, Kaphavata Prakriti people are 25\% and Vatapitta Prakriti people are $22.27 \%$ in the group. $11.36 \%$ people with excellent SHC had Sama Prakriti.

\section{Prakriti Wise Distribution of Volunteers with Good SHC:}

Table 3: Prakriti Wise Distribution of Volunteers with Good SHC:

\begin{tabular}{lcc} 
Prakriti & $\begin{array}{c}\text { Total number of } \\
\text { volunteers with } \\
\text { good SHC }\end{array}$ & $\begin{array}{c}\text { Percentage of volun- } \\
\text { teers with good SHC } \\
\text { (within the group) }\end{array}$ \\
Vata & 3 & 4.48 \\
Pitta & 4 & 7.46 \\
Kapha & 5 & 5.97 \\
Kaphapitta & 14 & 20.90 \\
Kaphavata & 21 & 31.34 \\
Vatapitta & 13 & 19.40 \\
Sama & 7 & 10.45 \\
Total & 67 & 100.00 \\
\hline
\end{tabular}

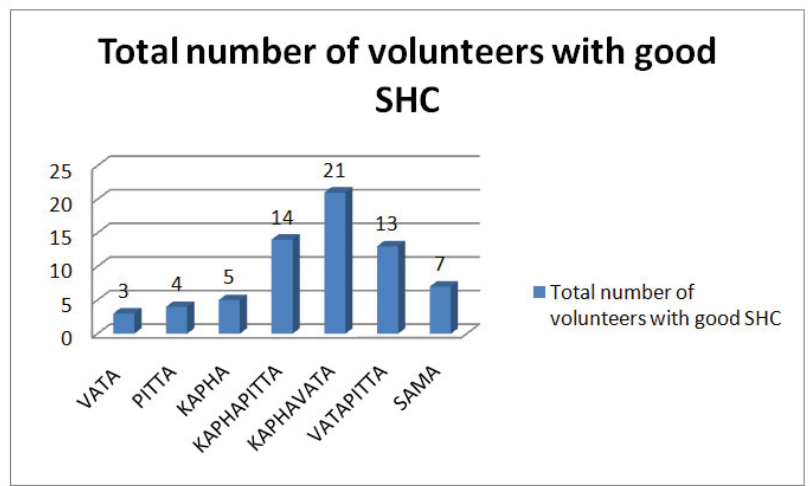

Figure 3A: Total number of volunteers with good SHC.

Table no 3 showed out of 138 participants, 67 participants had good SHC. 3, 4, and 5 participants with Vata, Pitta and Kapha Prakriti had good SHC. The highest number of participants with good SHC was from the group of Kaphavata Prakriti with 21 in number. The number of Kaphapitta Prakriti and Vatapitta Prakriti with good SHC was 14 and 13, respectively. 7 participants with Sama Prakriti had good SHC.

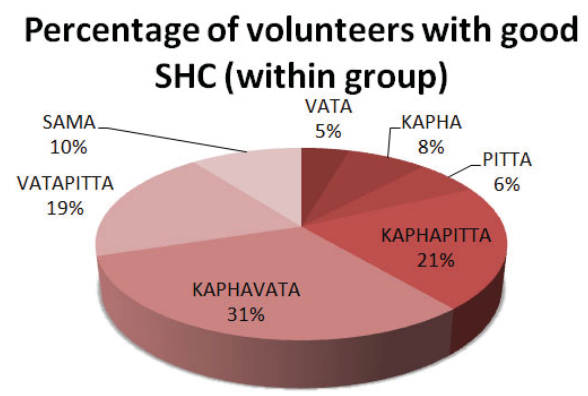

Figure 3B: Percentage of volunteers with good SHC (within the group). 
Diag. no 3 showed Duel Prakriti comprise $71.64 \%$ of the population of the group. Kaphapitta Prakriti people are $20.90 \%$ of the group, Kaphavata Prakriti people are $31.34 \%$ and Vatapitta Prakriti people are $19.40 \%$ in the group. $10.45 \%$ people with good SHC had Sama Prakriti.

\section{Prakriti Wise Distribution of Volunteers with Average SHC:}

Table 4: Prakriti Wise Distribution of Volunteers with Average SHC

\begin{tabular}{lcc}
$\begin{array}{l}\text { Assessment } \\
\text { of Prakriti }\end{array}$ & $\begin{array}{c}\text { Total number } \\
\text { of volunteers } \\
\text { with average } \\
\text { SHC }\end{array}$ & $\begin{array}{c}\text { Percentage of volunteers } \\
\text { with average SHC within } \\
\text { group }\end{array}$ \\
Vata & 2 & 7.41 \\
Kapha & 0 & 0.00 \\
Pitta & 0 & 0.00 \\
Kaphapitta & 0 & 0.00 \\
Kaphavata & 12 & 44.44 \\
Vatapitta & 11 & 40.74 \\
Sama & 27 & 7.41 \\
Total & & 100.00 \\
\hline
\end{tabular}

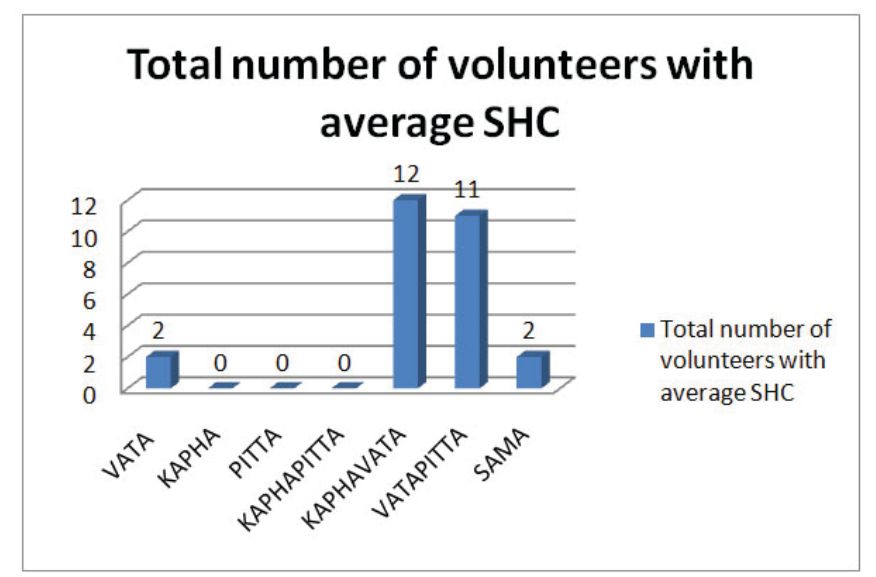

Figure 4A: Total number of volunteers with average SHC.

Table no 4 and Diag. no 4 showed out of 138 participants, 27 participants had average SHC. 2 participants with Vata Prakriti had average SHC. 12 participants with average SHC had Kaphavata Prakriti. 11 participants with Vatapitta Prakriti had average SHC. 2 participants with Sama Prakriti had average SHC.

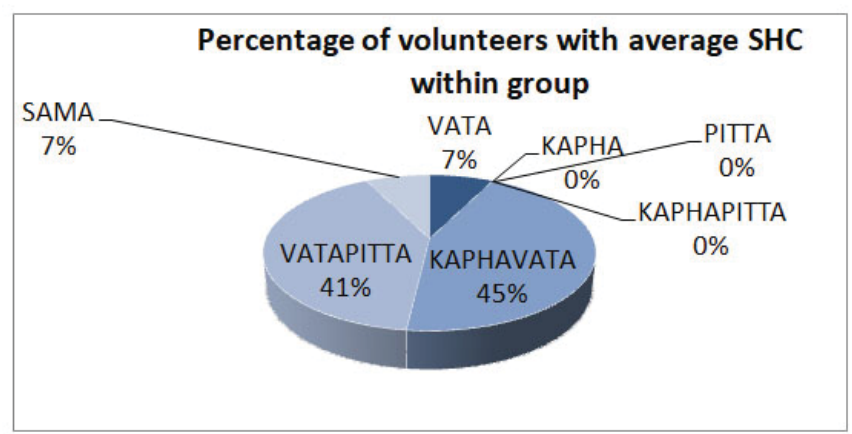

Figure 4B: Percentage of volunteers with average SHC within group.

Diag. no 4 b showed Duel Prakriti comprise $85.19 \%$ of the population of the group. No participant with Kaphapitta Prakriti said to have average SHC. Kaphavata Prakriti people are $44.44 \%$ and Vatapitta Prakriti people are $40.74 \%$ in the group. $7.41 \%$ people with average SHC had Sama Prakriti. No participant with Kapha Prakriti and Pitta Prakriti had average SHC.

\section{DISCUSSION}

Stress is an inevitable factor of life. One must know the management of it. When the mind is disturbed homeostasis of hormones and other vital components of the body (Dosha) is also disturbed. Diseases like hypertension, heart disease, diabetes are stress-induced. The psychosomatic constitution of a person describes his typical physical and psychological characteristics.

The psychological characters of Kapha prakriti people are that they never get angry or very depressed. They are tolerant to hardships, patient, and hardworking. They can easily forgive people. They are matured, polite, and decent people. They have good sleeping habits. ${ }^{9-11}$

The psychological characters of Pitta prakriti people are that they are brave, mighty, and radiant people. They are not defeated easily. They are fearless, short-tempered, unsparing to the bad people whereas soft-hearted towards good people. These people have very high intellect. ${ }^{12-14}$

Vata Prakriti people are mentally unstable, jealous, hotheaded, and violent. The people of Vata Prakriti experience emotions like anger, fear, and irritability quicker. They tend to sleep less and the sleep pattern is not very good. ${ }^{15-17}$

It is very rare that a person has one Dosha Prakriti. People generally have dual Dosha Prakriti. So they have psychosomatic characters of both the Dosha. One Dosha remains dominant in duel Dosha Prakriti. The dominant Dosha has more influence on the physical and psychological qualities of a person. People with Sama Prakriti have mixed type of characteristics. 
People with the dominance of Kapha are mentally strong. Their patient, tolerant, and hardworking nature makes them confident to handle difficult situations. When people have Kapha Dosha dominant in their constitution, they can handle stress very well. Good sleeping patterns also help them to maintain their hormone levels so that they remain calm and less stressed. ${ }^{18}$

Pitta Dosha dominant people are fearless, brave, and intelligent. Their intelligence and bravery give them the confidence to get through the challenges. ${ }^{19}$ Vata Dosha dominant people are mentally unstable, irritable, and coward. Due to these psychological factors, people with Vata dominant Prakriti find stress handling difficult. But if the person has Pitta dominant Vatapitta Prakriti, the person gets the benefits of Pitta in SHC

The volunteers for the present study are from the BAMS $\mathrm{I}^{\text {st }}$ and $\mathrm{II}^{\text {nd }}$ year students. Being students of a professional course, nobody assessed themselves extremely bad at stress handling. Hence, nobody came under the category of poor stress handlers. People with single Dosha Prakriti were very less in number in the sample as single Dosha prakriti is found very rarely.

$61.36 \%$ people with excellent stress handing had either $\mathrm{Ka}$ pha Vata or Kapha Pitta Prakriti. People with Kapha dominant Prakriti had excellent SHC. Vatapitta Prakriti people were 22. $73 \%$. Out of which $15.90 \%$ had Pitta dominant Prakriti. No person with Vata Prakriti had excellent SHC.

$52.24 \%$ people in good SHC group had Kapha Vata or Kapha Pitta Prakriti. Kapha Vata Prakriti people were maximum in number in good SHC. The group of Kaph Pitta prakriti people was on the second number in this group also. People of the Vata Pitta Prakriti were least in the duel Prakriti group with good SHC. The number of Kapha pitta prakriti people moved to the second position in the good SHC group. The Kapha Pitta Prakriti people assessed themselves as excellent in SHC; hence the number in this was reduced.

Interestingly, there was not a single person of Kapha, Pitta, or Kapha Pitta Prakriti who assessed themselves as average in SHC. The average SHC group had a dominant presence of Kapha Vata, Pitta Vata Prakriti, Vata and Sama Prakriti. The duel Prakriti was Vata dominant. The psychosomatic characteristics of Vata Dosha manifest in the form of bad SHC. Certain systemic conditions need careful attention like diabetes ${ }^{20-25}$, hypertension ${ }^{26-34}$, respiratory and renal disorders ${ }^{35-41}$. Many other related articles are available ${ }^{42-53}$.

\section{CONCLUSION}

Aptitude test, IQ test is very common assessment tools in our society for many years. If we assess the Prakriti of the people at early age, we can get a clue about their SHC. Stress management is very important in this modern world. The young generation is under tremendous stress due to their education, carrier, and jobs. With the help of correct Prakriti assessment, we can avoid stress-induced diseases.

\section{Scope for further study}

Bigger sample size can be taken for more accuracy.

Acknowledgement: Authors acknowledge the immense help received from Datta Meghe Ayurvedic Medical College Hospital \& Research Center, Wanadongri, Nagpur for conducting this study.

\section{Conflict of interest: None}

\section{REFERENCES}

1. Prasher, Bhavana, Sapna Negi, Shilpi Aggarwal, Amit K. Mandal, Tav P. Sethi, Shailaja R. Deshmukh, Sudha G. Purohit, et al. 'Whole Genome Expression and Biochemical Correlates of Extreme Constitutional Types Defined in Ayurveda'. Journal of Translational Medicine 6 (9 September 2008): 48. https://doi. org/10.1186/1479-5876-6-48.

2. Agrawal, Akash Kumar, C. R. Yadav, and M. S. Meena. 'Physiological Aspects of Agni'. Ayu 31, no. 3 (2010): 395-98. https:// doi.org/10.4103/0974-8520.77159.

3. Sushruta, Sushruta Samhita, Sutrastana, Doshadhatumalavigyaniyam Adhyayam,15/44, commentator Dr. Laxmidhar Dwivedi, Chaukhamba Sanskrit series office, Varanasi, $3^{\text {rd }}$ edition 2007;131

4. Assistant professor, Dept of Kaumarbhritya ,DY Patil School of Ayurved, and Dr. Sawant Sonia Madhukar. 'Psychological Stress Factor Inducing Juvenile Diabetes'. International Journal of Ayurvedic and Herbal Medicine, 6 February 2018. https:// doi.org/10.18535/ijahm/v8i1.02.

5. Jain, Nitu, Nov Rattan Sharma, and Amrita Yadava. 'Prakriti and well-being'. Psychology of Wellbeing, n.d., 12.

6. Mahalle NP, Kulkarni MV, Pendse NM, Naik SS. Association of constitutional type of Ayurveda with cardiovascular risk factors, inflammatory markers and insulin resistance. Journal of Ayurveda and integrative medicine. $2012 \mathrm{Jul} ; 3(3): 150$.

7. Tiwari, Dr Lalit. 'Scientific assessment of personality on the basis of doshaja and manas prakriti'. Vol. 8 (2019): 4.

8. Tripathi, Piyush Kumar, Kishor Patwardhan, and Girish Singh. 'The Basic Cardiovascular Responses to Postural Changes, Exercise, and Cold Pressor Test: Do They Vary in Accordance with the Dual Constitutional Types of Ayurveda?' Research Article. Evidence-Based Complementary and Alternative Medicine, 2011. https://doi.org/10.1155/2011/251850.

9. Agnivesha, Caraka, Dridhabala, Carakasamhita, Vimansthan, Rogbhishigjitiya Adhyay, 8/96, edited by Dr. Brahmanand Tripathi, Chaukhamba Surbharati Prakashan, Varanasi. 2017;759.

10. Sushrut, Sushrutsamhita, Sharirsthan, Garbha vyakarana Sharir, 4/71-75, commentator Dr. Bhaskar Govind Ghanekar, Meharchand Lachhmandas Publications, New Delhi, reprint 2017;141.

11. Vagbhata, Atridevgupt, Ashtanghridaya, Sharirsthan, 3/96103, edited by Yadunandan Upadhyay, Chaukhamba Surbharati Prakashan, Varanasi. 2018;262

12. Agnivesha, Caraka, Dridhabala, Carakasamhita, Vimansthan, Rogbhishigjitiya Adhyay, 8/97, edited by Dr. Brahmanand Tripathi, Chaukhamba Surbharati Prakashan, Varanasi. 2017;760. 
13. Sushrut, Sushrutsamhita, Sharirsthan, Garbha vyakarana Sharir, 4/67-70, commentator Dr. Bhaskar Govind Ghanekar, Meharchand Lachhmandas Publications, New Delhi, reprint 2017;141.

14. Vagbhata, Atridevgupt, Ashtanghridaya, Sharirsthan, 3/90-95, edited by Yadunandan Upadhyay, ChaukhambaSurbharatiPrakashan, Varanasi. 2018;261

15. Agnivesha, Caraka, Dridhabala, Carakasamhita, Vimansthan, Rogbhishigjitiya Adhyay, 8/98, edited by Dr. Brahmanand Tripathi, Chaukhamba Surbharati Prakashan, Varanasi. 2017;761.

16. Sushrut, Sushrutsamhita, Sharirsthan, Garbha vyakarana Sharir, 4/64-66, commentator Dr. Bhaskar Govind Ghanekar, MeharchandLachhmandas Publications, New Delhi, reprint 2017;140.

17. Vagbhata, Atridevgupt, Ashtanghridaya, Sharirsthan, 3/8489, edited by Yadunandan Upadhyay, Chaukhamba Surbharati Prakashan, Varanasi. 2018;260

18. Arthur C. Guyton, John E. Hall. Textbook of Medical Physiology. $11^{\text {th }}$ ed. Philadelphia: Elsevier publications; 2006.p.955-956

19. Upendranath Das. Tridoshvigyaniya. $4^{\text {th }}$ ed. Varanasi: Chaukhamba Amarbharti Prakashan; 1982.p.109

20. Bhinder, H.H.P.S., and T.K. Kamble. "The Study of Carotid Intima-Media Thickness in Prediabetes and Its Correlation with Cardiovascular Risk Factors." Journal of Datta Meghe Institute of Medical Sciences University 13, no. 2 (2018): 79-82. https:// doi.org/10.4103/jdmimsu.jdmimsu_58_18.

21. Cladius, S., U. Jadhav, B. Ghewade, S. Ali, and T. Dhamgaye. "Study of Diabetes Mellitus in Association with Tuberculosis." Journal of Datta Meghe Institute of Medical Sciences University 12, no. 2 (2017): 143-47. https://doi.org/10.4103/jdmimsu. jdmimsu_62_17.

22. Rathi, N., B. Taksande, and S. Kumar. "Nerve Conduction Studies of Peripheral Motor and Sensory Nerves in the Subjects with Prediabetes." Journal of Endocrinology and Metabolism 9, no. 5 (2019): 147-50. https://doi.org/10.14740/jem602.

23. Walinjkar, R.S., S. Khadse, S. Kumar, S. Bawankule, and S. Acharya. "Platelet Indices as a Predictor of Microvascular Complications in Type 2 Diabetes." Indian Journal of Endocrinology and Metabolism 23, no. 2 (2019): 206-10. https://doi. org/10.4103/ijem.IJEM-13-19.

24. Nagoba, B., M. Davane, R. Gandhi, B. Wadher, N. Suryawanshi, and S. Selkar. "Treatment of Skin and Soft Tissue Infections Caused by Pseudomonas Aeruginosa-A Review of Our Experiences with Citric Acid over the Past 20 Years." Wound Medicine 19 (2017): 5-9. https://doi.org/10.1016/j.wndm.2017.09.005.

25. Phadnis, P., M.A. Kamble, S. Daigavane, P. Tidke, and S. Gautam. "Prevalence and Risk Factors - Hemoglobin A1c, Serum Magnesium, Lipids, and Microalbuminuria for Diabetic Retinopathy: A Rural Hospital-Based Study." Journal of Datta Meghe Institute of Medical Sciences University 12, no. 2 (2017): 12132. https://doi.org/10.4103/jdmimsu.jdmimsu_59_17.

26. Yadav, S., M. Agrawal, C. Hariharan, D. Dewani, K. Vadera, and N. Krishna. "A Comparative Study of Serum Lipid Profile of Women with Preeclampsia and Normotensive Pregnancy." Journal of Datta Meghe Institute of Medical Sciences University 13 , no. 2 (2018): 83-86. https://doi.org/10.4103/jdmimsu. jdmimsu_70_17.

27. Papalkar, P., S. Kumar, S. Agrawal, N. Raisinghani, G. Marfani, and A. Mishra. "Heterotaxy Syndrome Presenting as Severe Pulmonary Artery Hypertension in a Young Old Female: Case Report." Journal of Gerontology and Geriatrics 66, no. 2 (2018): 59-61.

28. Charan, N., M. Choudhari, M. Sonkusale, and R. Deshpande. "Anesthetic Management of Chronic Thromboembolic Pulmo- nary Hypertension for Pulmonary Endarterectomy." Journal of Datta Meghe Institute of Medical Sciences University 12, no. 4 (2017): 289-91. https://doi.org/10.4103/jdmimsu.jdmimsu_40_17.

29. Gaikwad, K.B., N.G. Joshi, and S.P. Selkar. "Study of Nitrosative Stress in 'Pregnancy Induced Hypertension."' Journal of Clinical and Diagnostic Research 11, no. 3 (2017): BC06-8. https://doi.org/10.7860/JCDR/2017/23960.9396.

30. Yadav, S., M. Agrawal, C. Hariharan, D. Dewani, K. Vadera, and N. Krishna. "A Comparative Study of Serum Lipid Profile of Women with Preeclampsia and Normotensive Pregnancy." Journal of Datta Meghe Institute of Medical Sciences University 13, no. 2 (2018): 83-86. https://doi.org/10.4103/jdmimsu. jdmimsu_70_17

31. Kumar, S., P. Bhayani, D. Hathi, and J. Bhagwati. "Hyponatremia Initial Presenting Feature of Normal Pressure Hydrocephalus in Elderly Patient: A Rare Case Report.” Journal of Gerontology and Geriatrics 66, no. 3 (2018): 156-57.

32. Bhinder, H.H.P.S., and T.K. Kamble. "The Study of Carotid Intima-Media Thickness in Prediabetes and Its Correlation with Cardiovascular Risk Factors." Journal of Datta Meghe Institute of Medical Sciences University 13, no. 2 (2018): 79-82. https:// doi.org/10.4103/jdmimsu.jdmimsu_58_18.

33. Khatib, M.N., R. Kirubakaran, S. Gaidhane, A.H. Shankar, and Z. Quazi Syed. "Yoga for Improving Functional Capacity, Quality of Life and Cardiovascular Outcomes in People with Heart Failure.” Cochrane Database of Systematic Reviews 2017, no. 7 (2017). https://doi.org/10.1002/14651858.CD012015.pub2.

34. Varyani, U.T., N.M. Shah, P.R. Shah, V.B. Kute, M.R. Balwani, and H.L. Trivedi. "C1q Nephropathy in a Patient of Neurofibromatosis Type 1: A Rare Case Report." Indian Journal of Nephrology 29, no. 2 (2019): 125-27. https://doi.org/10.4103/ ijn.IJN_353_17.

35. Dhar, R., S. Singh, D. Talwar, M. Mohan, S.K. Tripathi, R. Swarnakar, S. Trivedi, et al. "Bronchiectasis in India: Results from the European Multicentre Bronchiectasis Audit and Research Collaboration (EMBARC) and Respiratory Research Network of India Registry." The Lancet Global Health 7, no. 9 (2019): e1269-79. https://doi.org/10.1016/S2214-109X(19)30327-4.

36. Dhamgaye, T.M., and D.S. Bhaskaran. An Unusual Pulmonary Metastatic Manifestation of Gestational Choriocarcinoma: A Diagnostic Dilemma. Lung India 34, no. 5 (2017): 490-91. https:// doi.org/10.4103/lungindia.lungindia_77_14.

37. Balwani, M., C. Bawankule, V. Ramteke, and A. Pasari. "Hepatitis C Virus, Directly Acting Antivirals and Guillain-Barré Syndrome." Saudi Journal of Kidney Diseases and Transplantation : An Official Publication of the Saudi Center for Organ Transplantation, Saudi Arabia 29, no. 5 (2018): 1237-39. https://doi. org/10.4103/1319-2442.243969.

38. Balwani, M.R., C. Bawankule, P. Khetan, V. Ramteke, P. Tolani, and V. Kute. "An Uncommon Cause of Rapidly Progressive Renal Failure in a Lupus Patient: Pauci-Immune Crescentic Glomerulonephritis." Saudi Journal of Kidney Diseases and Transplantation : An Official Publication of the Saudi Center for Organ Transplantation, Saudi Arabia 29, no. 4 (2018): 989-92. https://doi.org/10.4103/1319-2442.239632.

39. Balwani, M.R., A. Pasari, A. Meshram, A. Jawahirani, P. Tolani, H. Laharwani, and C. Bawankule. "An Initial Evaluation of Hypokalemia Turned out Distal Renal Tubular Acidosis Secondary to Parathyroid Adenoma." Saudi Journal of Kidney Diseases and Transplantation : An Official Publication of the Saudi Center for Organ Transplantation, Saudi Arabia 29, no. 5 (2018): 1216-19. https://doi.org/10.4103/1319-2442.243965. 
40. Dande, R., A.R. Gadbail, S. Sarode, M.P.M. Gadbail, S.M. Gondivkar, M. Gawande, S.C. Sarode, G.S. Sarode, and S. Patil. "Oral Manifestations in Diabetic and Nondiabetic Chronic Renal Failure Patients Receiving Hemodialysis." Journal of Contemporary Dental Practice 19, no. 4 (2018): 398-403. https:// doi.org/10.5005/jp-journals-10024-2273.

41. Balwani, M.R., A. Pasari, and P. Tolani. "Widening Spectrum of Renal Involvement in Psoriasis: First Reported Case of C3 Glomerulonephritis in a Psoriatic Patient." Saudi Journal of Kidney Diseases and Transplantation: An Official Publication of the Saudi Center for Organ Transplantation, Saudi Arabia 30, no. 1 (2019): 258-60.

42. Chandankar, Sneha Bhimrao, and Vaishali Kuchewar. "Management of Vipadika through Ayurveda." International Journal of Ayurvedic Medicine 10, no. 1 (March 2019): 122-24.

43. Deogade, Meena Shamrao, and Shiva Rama Prasad Kethamakka. "Krumi (Microorganisms) in Ayurveda- A Critical Review." International Journal of Ayurvedic Medicine 10, no. 4 (December 2019): 297-300.

44. Deogade, Meena Shamrao, and K. S. R. Prasad. "Standardization of Wild Krushnatulasi (OcimumTenuiflorum Linn) Leaf." International Journal of Ayurvedic Medicine 10, no. 1 (March 2019): 52-61.

45. Gupta, Rahul Kumar, and Meena Deogade. "A Critical Review on Ethnobotanical, Phytochemical and Pharmacological Investigations of MartyniaAnnua Linn." International Journal of Ayurvedic Medicine 9, no. 3 (September 2018): 136-43.

46. Gupta, Rahul Kumar, and Meena ShamraoDeogade. "Antioxidant Activities of MartyniaAnnua Linn. Root Extract." Inter- national Journal of Ayurvedic Medicine 10, no. 4 (December 2019): 326-28.

47. Hagone, Prajkta Anil, and Vaishali Kuchewar. "Management of Glomerulonephritis through Ayurveda - A Case Report." International Journal of Ayurvedic Medicine 10, no. 4 (December 2019): 345-47.

48. Kombe, Pooja, and Vaishali Kuchewar. "Evaluation of Effect of Kanchanar Guggul in Sub-Clinical Hypothyroidism with Respect to Agnimandya." International Journal of Ayurvedic Medicine 10, no. 4 (December 2019): 310-16.

49. Sawarkar, Punam, and Gaurav Sawarkar. "Peer-Assisted Learning of Procedural Skill in Basti Karma (Medicated Enema) A Pilot Study.” International Journal of Ayurvedic Medicine 10, no. 4 (December 2019): 317-22.

50. Sharma, Tarun, Bhargav Bhide, and Rabinarayan Acharya. "Ethnomedicinal Claims on Wound Healing Activity of Certain Leaf Drugs - A Review." International Journal of Ayurvedic Medicine 9, no. 2 (June 2018): 42-78.

51. Zanwar, Ashish Chhaganlal, and Sadhana Misar Wajpeyi. "Management of Hepatitis B (Carrier Stage) through Ayurved - A Case Report." International Journal of Ayurvedic Medicine 10 , no. 4 (December 2019): 342-44.

52. Wajpeyi, Sadhana Misar. "Role of Ayurveda in the Management of Guillain-Barre Syndrome Case Study.” International Journal of Ayurvedic Medicine 9, no. 4 (December 2018): 288-92.

53. Nishikant A. Ingole, Ranjit S. Ambad. Pharmacoeconomic Study of the Prescription Pattern of Psychotic Disorders in Psychiatry OPD. JMSCR Volume 05 Issue 08 August 2017; P 26105-26109. 